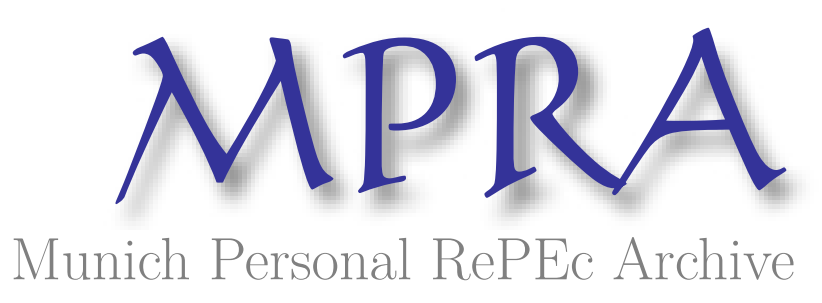

\title{
Development of Potato in Bihar:Issues and Strategies
}

Singh, K.M. and Kumar, Abhay

ICAR-RCER, Patna, India

3 November 2013

Online at https://mpra.ub.uni-muenchen.de/51862/

MPRA Paper No. 51862, posted 03 Dec 2013 22:38 UTC 


\title{
Development of Potato in Bihar-Issues and Strategies
}

\author{
K.M.Singh ${ }^{1}$ and Abhay Kumar ${ }^{2}$
}

\begin{abstract}
Potato is the fourth major food crop after rice, wheat and maize in Bihar. It occupies less than $5 \%$ of net sown area with production only $4^{\text {th }}$ after rice, wheat and maize. Potato a short duration crop has special significance since it gives exceptionally high yields/unit area/unit time and has high nutritional value to sustain burgeoning population and ward off hunger and malnutrition. Potato produces more food, edible energy and edible protein per unit area and time as compared to any other food crop. Potato provides excellent opportunities in rasing the income of the farmers as it has capacity to yield 5-10 times more than cereals, pulses or oilseeds. Efficient marketing is crucial for a successful diversification and commercialization of potato and accelerated farmer income growth. At present, marketing of potato in the state is highly unorganized. Bihar's density of the market (per $\mathrm{m}$ ha of sown area) is relatively low. Potato from Bihar is transported to other market in the country for which cheap road transport and better marketing facilities are essential. Emphasis should be put on the establishment of new cold stores, processing industries in the production catchments to minimize transport cost, create employment opportunities in the rural sector. There is challenge to enhance productivity and quality under conditions of shrinking arable land, reduced water availability, changing climatic conditions and expanding biotic and abiotic stresses. However, with increase in production, recurring gluts are common in the country. The price crashes drastically during months of plenty, leading to distress sell by farmers and incurring substantial monetary loss. To absorb excess potato production and sustain the growth, there is need for diversified and increased utilization and export of potatoes. The article tries to explore the current scenario, the constraints and possible solutions for enhancing potato cultivation in India in general and Bihar in particular.
\end{abstract}

Key words: Potato, Potato trade and markting, Potato production, Bihar, India

\footnotetext{
${ }^{1}$ Principa Scientist and Head, Division of Socio-Economics and Extension, ICAR-RCER, Patna, 800014, Bihar Email: m.krishna.singh@gmail.com (Corresponding author)

${ }^{2}$ Principal Scientist, Division of Socio-Economics and Extension, ICAR-RCER, Patna
} 


\section{Development of Potato in Bihar: Issues and Strategies}

Bihar represents the great Indo-Gangetic plains, one of the most fertile lands of the world. It offers salubrious agro-climatic conditions for growing a wide range of crops. Agriculture is the back bone of Bihar economy, employing about $80 \%$ of the work force and generating nearly $42 \%$ of the state domestic product. Bihar share of agriculture in national GDP is $39 \%$ as against $24.3 \%$ of the country's share, due to the fact that the $89.5 \%$ of the population of the state have rural and farming background. Bihar ranks $10^{\text {th }}$ in area and $3^{\text {rd }}$ in population with per capita income of about $14^{\text {th }}$ of the nation. Bihar is most populace state of India with a population of 83 million and population growth of about $2.43 \%$ per annum, having highest density of population among rural India. About $40 \%$ of the populations are under below poverty line.

Potato is the fourth major food crop after rice, wheat and maize in Bihar. It occupies less than $5 \%$ of net sown area with production only $4^{\text {th }}$ after rice, wheat and maize. Potato is highly nutritious, easily digestible and regarded as wholesome food having vast potential for ensuring food and nutritional security for millions of people of state. In Bihar, large population accompanied with poverty poses serious problems. These problems besides having close relationship with food insecurity are also related to poor health as a result of malnutrition. Moreover, increasing population, rapid urbanization and manmade creation of waste lands is causing shrinkage of arable land and water resources. At the same time declining input use efficiency, emergence of resistant pest and diseases and declining output: input ratio have resulted in making farming less and less remunerative for resource poor farmers of the state. Under this scenario, potato a short duration crop has special significance since it gives exceptionally high yields/unit area/unit time and has high nutritional value to sustain burgeoning population and ward off hunger and malnutrition. Potato produces more food, edible energy and edible protein per unit area and time as compared to any other food crop. The dry matter production in potato is about $47.6 \mathrm{~kg} /$ ha / day whereas wheat, rice and maize produce only 18.1, 12.4 and $9.1 \mathrm{~kg} /$ ha / day respectively. Potato, thus, holds major potential in eradicating hunger and malnutrition and providing food and nutritional security to ever increasing population. The task before the state of Bihar is to increase the production and quality of potato to meet the domestic requirements with in the states and exportable surplus to earn foreign exchange. 


\section{Potato production situation}

India is the world's third largest potato producing country. During the past 60 years the potato has shown spectacular growth in area, production and productivity in India with increase in area production and productivity over this period by 6.6, 18.51 and 2.80 times respectively. The potato productivity in India (18.4t/ha) is little better than world average (16.6 t/ha) however, it is much lower than many of the countries of Europe and America such as Netherlands (42.4t/ha) because it is grown as short duration crop in India. The estimated total production in India for 2009-2010 was around 34 million tones from 1.55 million hectares. At present Bihar ranks third after Uttar Pradesh and West Bengal in potato area and production among different states of India. In Bihar potato is grown in 0.32 million hectare with annual production of 5.74 million tones having productivity of $17.78 \mathrm{t} / \mathrm{ha}$. Potato is grown in all the 38 districts of Bihar (Table-1), but the major contributors are Nalanda, Patna, Saran, Samastipur, Gopalganj Vaishali, East and West Champaran, Muzaffarpur and Siwan which account for 80 percent of the area. Productivity wise Nalanda, Patna and Begusarai are foremost districts. However, $\operatorname{Bihar}(17.78 \mathrm{t} / \mathrm{ha})$ which is sandwiched between high productive states West Bengal (24.70 t/ha) and Uttar Pradesh (21.97 t/ha) has always been the concern for policy planners for its low productivity despite the fact that it is blessed with high fertile land and good quality water resources.

Table:1.Area, Production and Productivity of potato in major Districts of Bihar (2009-10)

\begin{tabular}{|l|c|c|c|}
\hline \multicolumn{1}{|c|}{ District } & Area(ha) & Production(t) & Yield(t/ha) \\
\hline Patna & 16050 & 409400 & 25.50 \\
\hline Nalanda & 27000 & 653320 & 24.19 \\
\hline Rohtas & 10700 & 195100 & 18.23 \\
\hline Gaya & 11500 & 190240 & 16.54 \\
\hline Saran & 13500 & 249970 & 18.51 \\
\hline Siwan & 10300 & 113460 & 11.01 \\
\hline Gopalganj & 12200 & 210470 & 17.25 \\
\hline East Champaran & 11750 & 202750 & 17.25 \\
\hline West Champaran & 12200 & 201300 & 16.50 \\
\hline Muzaffarpur & 12000 & 210980 & 17.58 \\
\hline Vaishali & 13500 & 255040 & 18.89 \\
\hline Madhubani & 10600 & 168040 & 15.85 \\
\hline Samastipur & 12300 & 250910 & 20.39 \\
\hline Others & 149240 & 2430310 & 16.28 \\
\hline Total & 322840 & 5741290 & 17.78 \\
\hline
\end{tabular}

(Source: Directorate of Horticulture, Govt. of Bihar) 


\section{Opportunities, Challenges and strategies}

Under the situation of increasing demand for food and diminishing per capita availability of land for agriculture due to rising population in India, the importance of potato for ensuring sustainability in agriculture and the food production is immense. Potato is a high yielding crop. Due to high protein - calorie ratio (17gm protein: $1000 \mathrm{Kcal}$.) and short vegetative cycle, potato yields substantially more edible energy, protein and dry matter per unit area and time than many other food crops. It produces $3 \mathrm{~kg}$ of protein/ha/day as compared to only $2.5 \mathrm{~kg} / \mathrm{ha} /$ day in wheat, $1.2 \mathrm{~kg} / \mathrm{ha} / \mathrm{day}$ in maize and $1.0 \mathrm{~kg} / \mathrm{ha} / \mathrm{day}$ in rice. This is of considerable importance in India where energy supplies are most readily available than the protein supplies.

Potato provides excellent opportunities in rasing the income of the farmers as it has capacity to yield 5-10 times more than cereals, pulses or oilseeds. The high profitability of potato as a cash crop has made it an economically viable enterprise for the small and marginal farmers and has contributed to increasing equity among farmers in the sub-tropics. Potato provides higher unit return and offers great scope for value addition. Potato has high employment generation potential during crop raising, post harvest handling, processing and value addition. Potato requires an input of 250 mandays for cultivation of the crop in one hectare area. The cultivation of potato in 1.4 million hectare area generates rural employment to the level of 350 million mandays annually. In addition employment opportunities are generated in the post harvest operations of storage, processing and value addition, transportation and marketing.

Potato is grown in multiple cropping systems in rotation with other vegetable or cereal crops. Potato responds well to input and gives high returns. The residual potash and phosphorus of the crop are generally adequate and the nitrogen requirement is reduced by half for good growth of succeeding cereal crops. Thus it contributes towards improved management of natural resources and optimization of fertilizer use which are essential for sustainable agricultural production.

The land resources being inelastic, the potential of increasing the area under cultivation is limited. Due to stiff crop competition there is very little possibility to have more area under potato crop. Short duration and cultural flexibility are potato's valuable trait that help in sandwiching this crop in various intensive cropping systems without putting much 
pressure on scarce resources such as land, water and fertilizer and resulting in expansion of potato area and production.

According to estimates published by the international food policy research Institute (IFPRI) and international potato centre (CIP), India is likely to have the highest growth rates in both production and productivity of potato. According to these growth rates the total production in India by 2020 would be around 43.3 million tones. There are several challenges to achieve these targets. Some of them are increasing population, decreasing arable land, reducing water availability, improved purchasing power leading to requirement of more food, environmental degradation, reduction in input use efficiency and adverse changes in climate and sea levels. Since, land and water are shrinking resources for agriculture; there is no other option except to produce more food from less land and water. In other words, we have produced more food per unit land, water, energy and time. Under this scenario some of the strategies to increase potato production in environmentally, economically and socially sustainable manner are given below:

\section{Processing and value addition}

Processing is a fast growing sector in the potato world economy. Potato can be processed in to several products like chips, French fries, flakes, dice, cubes, granules and canned potato on a commercial scale. In India only less than $6 \%$ of total potato harvest is used for post harvest processing as compared to $60 \%$ in USA, 55\% in the Netherlands and $25 \%$ in China. In recent years the demand for processed potato products in the country has risen at fast pace due to increased urbanization, rise in per capita income, increase in number of working women and expanding tourism. About $90 \%$ of total potato processing in India is done in the unorganized sector which provides a lot of employment to landless, marginal and small farmers. In India potato processing in organized sector started about a decade ago. Development of processing cultivars namely Kufri Chipsona-1, Kufri Chipsona-2 \& Kufri Chipsna-3 which is now being used by the industries for making chips and French fries, has accelerated growth in processing sector. However, French fries are not as popular here as in the developed countries because of lack of cold chain facility essential for its transport and marketing. With the coming up of large companies. in the potato processing sector the demand for a processing quality potato is increasing exponentially.

Processing of potato to produce industrial raw material like starch is another area, which has not received much attention so far. Potato starch is superior to cereal starches for 
sizing and surface coating in paper industry, in sizing of cotton and in finishing sewing thread and cloth in textile industry. In food industry potato starch is also used in instant puddings, as an additive to some bread and biscuits and as thickener in soups. There is plenty of growth expected in this sector in near future.

There appears a great potential of potato processing in Bihar since at present this is negligible. There is complete lack of processing unit and absence of any established processing facility in the state. The produce is mostly marketed fresh with negligible processing and value addition. There are no organized processing industries in the state. Less than $1 \%$ of the potato is processed in Bihar. Some village level processing of potatoes in to chips and papad etc. is in practice in unorganized sector. The processing segment is marked by a complete absence of cold chain along the value chain resulting in quality deterioration. The state is not yet prepared to absorb excess potato production and thus attention need to be given for development of policies for promoting processing and exports. As a matter of the fact with proper development of markets, cold storages, transportation and processing, potato products can be marketed to other states and even to foreign countries, which will improve the farmer's income.

Unlike north India, the spell of cold winter is short in Bihar and therefore, optimum date for planting potato is mid November and afterwards (this is also because of late paddy harvesting). Thus potato harvesting often takes place during late February to mid March. The weather during these days is warmer. It is an established fact that weather condition supporting relatively high temperature during later phase of crop growth and at the time of potato harvest; facilitates better quality of processing tuber with less reducing sugar and more dry matter. One can expect the dry matter content of $18-20 \%$ when the average minimum temperature is between 10 and $12^{\circ} \mathrm{C}$. When the average minimum temperature is more than $12^{\circ} \mathrm{C}$, the dry matter is $20 \%$ and more, accompanied with low level of reducing sugars. Major areas in Bihar fall in most suitable category of potato production for processing. The average maximum and minimum temperature during crop growth period at Patna are $25.9^{\circ} \mathrm{C}$ and $13.1^{\circ} \mathrm{C}$ respectively. Potatoes of variety Kufri Jyoti grown at Patna have a dry matter content ranging from 20 to $21 \%$. Generally, dry matter content above $20 \%$ is considered good. The reducing sugar content upto $250 \mathrm{mg} / 100 \mathrm{~g}$ fresh weight is considered acceptable for processing potatoes into chips. 
Table 2. Percentage of Tuber Dry Matter in Processing Varieties Grown at Different Places

\begin{tabular}{|l|c|c|c|r|}
\hline \multicolumn{1}{|c|}{ Variety } & Badaun & Modipuram & Patna & Indore \\
\hline Kufri Chipsona-1 & 22.6 & 20.3 & 24.0 & 22.2 \\
\hline Kufri Chipsona-2 & 22.6 & 20.1 & 22.0 & 20.3 \\
\hline Kufri Jyoti & 19.7 & 17.7 & 18.4 & 18.8 \\
\hline
\end{tabular}

Table 3. Average Maximum And Minimum Temperature During Crop Season At Different Locations (Mean of 30 Years)

\begin{tabular}{|l|c|c|c|}
\hline \multirow{2}{*}{ Region } & \multicolumn{2}{|c|}{ During crop growth } & During crop maturity \\
\cline { 2 - 4 } & $\begin{array}{c}\text { Average maximum } \\
\mathbf{0}\end{array}$ & $\begin{array}{c}\text { Average minimum } \\
\mathbf{(} \mathbf{~ C )}\end{array}$ & $\begin{array}{c}\text { Average minimum } \\
\mathbf{(}\end{array}$ \\
\hline Amritsar & 24.6 & 8.6 & 4.5 \\
\hline Hisar & 27.5 & 9.7 & 5.5 \\
\hline Kota & 29.1 & 14.4 & 10.6 \\
\hline Meerut & 25.5 & 11.1 & 9.8 \\
\hline Gwalior & 26.0 & 8.8 & 10.0 \\
\hline Kanpur & 26.9 & 12.0 & 11.0 \\
\hline Indore & 27.6 & 10.6 & 11.0 \\
\hline Patna & 25.6 & 13.1 & 13.4 \\
\hline
\end{tabular}

Now awareness is increasing regarding the suitability of Bihar for producing potatoes fit for processing purposes. Potato processing companies are doing contract farming and transporting the stocks to far off places for processing. Since potato processing firms at present do not exist in Bihar, there is outflow of limited material to outside state for processing. It is very likely that firms will now be established within the state to make use of the best suited produce for processing.

\section{Unorganized Marketing and price fluctuation}

Efficient marketing is crucial for a successful diversification and commercialization of potato and accelerated farmer income growth. At present, marketing of potato in the state is highly unorganized. Bihar's density of the market (per $m$ ha of sown area) is relatively low. 
There are seven principal regulated markets for every million hectare of area in Bihar compared to 22 in the state like Andhra Pradesh. The amount and quality of market infrastructure and support services is poor. Potato marketing facilities are not adequately developed in the state. Potato marketing in the state in particular and country in general suffers from high marketing cost and margin, wide price fluctuation, bottleneck in storage facilities, lack of long term Indian potato export policy and lack of avenues for utilization of potato. Lack of cold chain facilities deteriorates the quality of produce by the time it reaches its destination.

Potato crop is produced seasonally but marketed throughout the year. Most of potato in state is harvested during January-March. Due to lack of cold storage facility farmer do not find adequate place to keep their produce safely. This compels farmers to reach market with all their produce at a time immediately after harvest. This causes sudden price crash during peak harvesting season and farmers are forced to sale the produce at very nominal price and not getting remunerative price. There is need to organize the marketing system to ensure better return to the growers. On the other hand price shoots up in the lean months of AugustDecember when fresh potatoes are not available. These causes price fluctuation. The arrival of potato in the market and the prices are very varied over time which introduces elements of uncertainty that affects both producers and consumers. Due to unpredictable prices, farmers do not take proper decision about planting area and also time of the sale of their harvested potato. Gluts are more common and severe due to high potato production, causing heavy monetary losses to farmers. This discourages farmers of potato cultivation. To avoid gluts and price crash a part of production can be diverted to processing and export.

\section{Infrastructure}

Rural connectivity is the key to raise the farmer's income and productivity. There are problems of proper communication and Transport in rural areas. The poor farmers cannot afford to transport there produce to the distant markets/cold stores on account of nonavailability of transport facilities and high transportation cost. Therefore, utmost priority should be given to improve connectivity by constructing good roads in the rural area in all districts. Linking of all production areas with all weather roads is necessary. Proper communication and transport system have direct impact on the farmer. Handling of the potato still becomes worse because of high moisture content and tropical climates under which physiological spoilage and microbial damages take place quit fast. Potato being a semi perishable commodity requires quick and cheaper transport. Lack of adequate transport 
facilities causes substantial loss of potato. Creating infrastructure like grading centre, pre cooling units, cold storage, transport vehicles etc. are urgently required to reduce post harvest losses and increase farmer's profitability. Potato from Bihar is transported to other market in the country for which cheap road transport and better marketing facilities are essential. Emphasis should be put on the establishment of new cold stores, processing industries in the production catchments to minimize transport cost, create employment opportunities in the rural sector.

\section{Human Resource Development}

Potato production is highly technology driven coupled with hi-tech interventions. For meeting the growing demands of the sector, it is necessary to have skilled man power at different levels. More over the acquired skills need to be updated periodically. Skilled man power will not only face the challenges of rapid development but also help accelerating the pace of growth of the sector. To train the man power there should proper coordination among different agriculture extension institutions, state government, financial intuitions and farming community. Training programmes for farmer at Panchayt and Block levels should be organized on a regular basis for adopting modern technologies more effectively. Transfer of technologies should be intensified at Grampanchayat level for keeping the farmers aware of the latest farm technologies.

Agricultural research intistutes/KVKs can be involved for training and demonstration of package of practices for organic agriculture and capacity building of the farmers. Appropriate network of extension services needs to be created to stimulate and encourage both top-down and bottom-up flows of information between farmers, extension workers and research scientists.

\section{Socio economic condition of farmer}

Land holding in Bihar consists predominately of small farms and holdings with high degree of fragmentation. Majority of farmers of the state, about $86 \%$ of our farmers are small and marginal. The average size of holdings is declining, having fallen to around 0.6 ha, and majority of farmers have less than 1 ha each. High population density has pushed up the intensity of the cultivation: the total cultivated area is around $60 \%$ compared with $47 \%$ nationally. With the average size of land holding shrinking as a result of increasing fragmentation, many marginal farms are becoming economically non-viable and oriented towards subsistence. Land consolidation has not being done in the state. Farmers have their 
fragmented small land holdings at several location, which restrict them to create basic facilities of irrigation, fencing and transport. Consolidation of land in the state should be priority.

The crop is very much labour intensive and requires high inputs. Most of the farmer growing potatoes are small and marginal having small holdings, who do not have capital to purchase expensive inputs. They generally, purchase sub-standard (small grade) seed tuber from local market for growing potatoes. The financing institutions with their complex procedure for sanction of loan are not easily accessible to the farmers. They rather prefer to continue with their traditional practices with low inputs. Poor input supply and support services have direct impact on potato production. Besides, Lack of awareness among farmers of scientific potato cultivation results in low productivity. There is poor adoption of improved agro-techniques of potato production because of inadequate education and lack of technical knowledge. Limited use of improved agricultural implements is another constraint.

Non-availability of genuine fertilizers and agro-chemicals at right time is also a problem. Invariably phosphatic and potassic fertilizers are not available at desired time. The less use of phosphatic and potassic fertilizer results in poor yield. Reliable and timely availability of quality inputs at reasonable prices, institutional and credit support, especially for small and resource poor farmer are lacking.

Lack of procurement policies and support price from state/Central government has adversely affected the potato production. There is no mechanism to compensate the farmers for loss of the crop due to serious disease like late blight.

\section{Utilization}

The diversified uses of potato cover fresh food, processed food, animal feed and starch. In recent years the demand of process food has increased many folds. Therefore, with increase in potato production there is a need for its diversified uses to avoid gluts situation and drop in market prices. In India about $73 \%$ potatoes are consumed as fresh food in the form of vegetables, $10 \%$ as a seed, less than $4 \%$ as processed and another less than $1 \%$ is exported and about $10-12 \%$ goes as waste. In India potatoes are not used as animal feed or as an industrial raw material for production of starch and alcohol.

Potato is staple food of several developed countries. Unfortunately in our country potato is still treated as vegetable as a result the per capita consumption of potato in India remains much less as compared to other parts of the world. The per capita consumption of 
potato in India is about $16 \mathrm{~kg} /$ person/year which is much less than European countries (136 $\mathrm{kg} /$ person/year in Poland, $129 \mathrm{~kg} /$ person/year in Ukraine). The main reasons for low per capita consumption are several false notions about the food value of potato. Many people are unaware of nutritive value of potato. Many people think that potato is all starch and nothing else. This is the impression people have not only in India but also in a developed country like UK. Potato is a low energy food and $100 \mathrm{gm}$ of boiled potato provides only $69 \mathrm{Kcal}$. But it has been blamed of being a calories rich food causing obesity. Another, misconception is that potato contains fat, therefore, cause obesity. The fat content in potato is not more than $0.1 \%$ but they can absorb considerable fat during frying. The real culprit is not potato but the fat which it absorbs. Potato is wrongly blamed of causing obesity while the real cause is our unhealthy food habits where a plenty of fat is used in potato recipes. Potato contains about $14 \%$ starch on fresh weight basis. Potato provides balanced quantities of carbohydrates (16$20 \%)$, proteins $(2-3 \%)$, minerals $(1 \%)$, fat $(0.6 \%)$ and high quality dietary fiber $(0.6 \%)$ and a number of vitamins.

Potato is a good source of high quality protein, because all amino acids are present in potato protein in comparatively large quantities and in a harmonized quantitative ratio. Lysine content in potato is similar to that in a typical animal protein. Potato has high lysine content and can supplement diets which are limiting in lysine such as rice. The potato is also a good source of vitamins. Potato contains $20-30 \mathrm{mg}$ of vitamin C per $100 \mathrm{gm}$ of tuber fresh weight i.e. higher than other vegetables. Potato also contains a good quantity of vitamins of B group and contributes substantially to the daily requirements of thiamin, niacin, riboflavin, folic acid, pyridoxine and it derivatives (Vitamin B-6 group) and pantothenic acid. Potato also provides high amount of iron, phosphorus, potassium and magnesium in better assimilative forms. The net protein utilization or biological value of potato protein (about $71 \%$ that of whole egg) is better than of wheat (53\%), maize (54\%), Pea (48\%), beans (46\%) and is comparable to cows milk (75\%).

There is ample room for increasing its consumption. To improve per capita consumption of potatoes, publicity campaigns needs to be launched through mass media such as television, radio and newspaper. It is opportune time to consider potato as staple food in our country where more than 30 per cent populations live under repressing food insecurity. 


\section{Home and international trade}

Only $2-3 \%$ of about 322 million tones of world potato production are traded internationally. Import and export of fresh potatoes to and from developed countries account for 83 and $86 \%$ of total world trade respectively. Although, India contributes $8 \%$ of the total world potato production, its $0.52 \%$ share in world potato export is not commensurate with its production figure. Table potatoes dominate our potato export, contributing about $50 \%$ of total potato export followed by frozen potatoes $(28 \%)$, Seed potatoes $(10 \%)$, and chips fried (8\%) and other frozen preparation (3\%). India has advantage for trade of fresh potatoes, seed potato and processed products. Indian potatoes are free from the prohibited disease like wart, black scarf and pest like tuber moth and nematodes, which are barometer for phyto-sanitary standards.

In temperate developed countries fresh potatoes are available only after September where as about $90 \%$ of fresh potatoes in India are harvested during January-March. India has, thus, the natural advantage of exporting fresh table potatoes during January-June when supply from European countries dwindles. It can also supply fresh potatoes round the year because India has diverse agro-climates and potato is grown throughout the year in one or the other part of the country. Moreover Indian potatoes are produced at low production cost, which provides competitive edge in the international market. India is likely to have highest growth rate in production and productivity of potatoes during 2010-2020. During the same period world wide demand of potatoes is expected to increase by $40 \%$. Hence, there is great scope for export of Indian potatoes to international market. Surveys of potential export market and strengthening of suitable infrastructure for export like cold storage, surface transportation and shipping facilities are essential components for for successful exports. The data base on potato export, price, grade standard, phytosanitary standard, processing standards, consumer preference, seed standard etc. needs to be prepared for all importing countries so that all information is readily available to the exporters and manufacturers.

\section{Conclusion}

Potato is one of the few foods capable of nourishing the population of the world. It is estimated that by 2020 India will have a population of 1.3 billion. This will require the country to produce about 49 million tones of potato. To achieve this production target, the productivity per unit area and time has to be increased. Adoption of improved technologies would be imperative to achieve the desire productivity level. Moreover, there is challenge to 
enhance productivity and quality under conditions of shrinking arable land, reduced water availability, changing climatic conditions and expanding biotic and abiotic stresses. However, with increase in production, recurring gluts are common in the country. The price crashes drastically during months of plenty, leading to distress sell by farmers and incurring substantial monetary loss. To absorb excess potato production and sustain the growth, there is need for diversified and increased utilization and export of potatoes.

\section{References:}

Basu, J.P. (2010), Efficiency in wholesale, retail and village markets: A study of potato markets in West Bengal, Journal of South Asian Development, 5(1):85-112

CIP (International Potato Center) (2006), India, World Potato Atlas.

Government of Bihar (2006), Bihar: Approach to the $11^{\text {th }}$ Five Year Plan: Vision for Accelerated Inclusive Growth, Planning and Development Department, Patna

Gulati, A., Minot, N., Delgado, C., Bora, S. (2007), Growth in High-Value Agriculture in Asia and the Emergence of Vertical Links with Farmers, In: Swinnen, J.F.M. (ed). Global Supply Chains, Standards and the Poor. CABI Publishing, Oxford.

Kumar, B. (2009), Indian Horticulture Database 2008, National Horticulture Board, New Delhi

Minten, B., Reardon, T; Singh,K.M. and Sutradhar, R. (2010).The benefit of cold storages: Evidence from Bihar (India). IFPRI Memeo Unpublished, NAIP. ICAR-RCER, Patna P.55.

Minten, B., Reardon, T; Singh,K.M. and Sutradhar, R. (2011). The potato value chain in Bihar: An assessment and policy implications. IFPRI Memeo Unpublished, NAIP. ICAR-RCER, Patna P.51

Nagara, J.R., Rahman, A. (2010), Booming Bihar: Fact or Fiction, Economic and Political Weekly, XLV(8): 10-11

Sharma, A.N. (2005), Agrarian relations and socio-economic change in Bihar, Economic and Political Weekly, March 5, pp. 960-972

World Bank (2007), Bihar agriculture: Building on emerging models of "success", Agriculture and Rural Development Sector Unit, South Asian Region, Discussion Paper Series, Report No.4, Washington DC

World Bank (2005), Bihar: Towards a Development Strategy, Washington DC 